\title{
Effect of Parathyroid Hormone on Rat Heart Cells
}

\author{
Eitan Bogin, Shaul G. Massry, and Isaac Harary, Division of Nephrology \\ and Department of Medicine, University of Southern California School of \\ Medicine, and Laboratory of Nuclear Medicine and Radiation Biology, \\ Department of Biochemistry, University of California Los Angeles \\ School of Medicine, Los Angeles, California 900.33
}

\begin{abstract}
A B S T R A C T Myocardiopathy is common in uremia, but its cause is unknown. Excessive entry of calcium in heart cells by catecholamines has been shown to cause necrosis of myocardium. The high blood levels of parathyroid hormone (PTH) in uremia may also enhance entry of calcium into heart cells and exert deleterious effects on the heart. We examined the effect of PTH on rat heart cells grown in culture. Both amino-terminal (1-34) PTH and intact (1-84) PTH, but not the carboxy-terminal (53-84) PTH produced immediate and sustained significant rise in beats per minute and the cells died earlier than control. The effect was reversed if PTH was removed from medium, and was abolished by inactivation of the hormone. There was a dose-reponse relationship between both moieties of PTH and the rise in heart beats, but the
\end{abstract} effect of 1-84 PTH was significantly greater than that of 1-34 moiety. PTH stimulated cyclic AMP production within $1 \mathrm{~min}$, and cyclic AMP remained significantly elevated thereafter. The effect of PTH required calcium, was mimicked by calcium ionophore, was prevented by verapamil and was not abolished by $\alpha$ - or $\beta$-adrenergic blockers. PTH action was additive to phenylephrine and synergistic with isoproterenol. Sera from uremic parathyroidectomized rats did not affect heart beats, but sera from uremic rats with intact parathyroid glands or from uremic-parathyroidectomized rats treated with PTH had effects similar to PTH. Data indicate that $(a)$ heart cell is a target organ for PTH and may have receptors for the hormone; (b) PTH increases beating rate of heart cells and causes early death of cells; $(c)$ PTH effect appears to be due to calcium entry into heart cells; (d) the locus of action through which PTH induces calcium entry is different from that for catecholamines;

\footnotetext{
Address reprint requests to Dr. Shaul Massry, Chief, Division of Nephrology, Department of Medicine, University of Southern California School of Medicine, Los Angeles, Calif. 90033.

Received for publication 19 August 1980 and in revised form 22 December 1980.
}

and $(e)$ uremic serum has no effect unless it contains PTH. Data suggest that myocardial damage may occur in uremia due to prolonged exposure to very high blood levels of PTH, and assign new dimensions to PTH toxicity in uremia.

\section{INTRODUCTION}

Patients with advanced renal failure may suffer from myocardial disease (1-6). Several consequences of uremia have been implicated, such as anemia, electrolyte disturbances, acidosis, and hypertension $(5,7)$. Accelerated atherogenesis has also been suggested as the cause of heart disease in these patients (8). However, myocardiopathy of unexplained etiology has also been reported (6).

Patients with renal failure have secondary hyperparathyroidism $(9-11)$, and markedly elevated blood levels of parathyroid hormone $(\mathrm{PTH})^{1}(12-14)$. The studies of Selye (15) and Lehr (16) suggested a role for PTH in the cardiac disease of uremia. These authors found that cardiac lesions predictably occurred in rats after bilateral nephrectomy or bilateral ureteral ligation. The lesions were characterized by calcium deposits in the myocardium and the coronary arteries. Administration of PTH enhanced the development of these lesions and parathyroidectomy either inhibited or completely prevented their evolution.

PTH is known to augment entry of calcium into a variety of mammalian cells (17-22), and it has been shown that excess blood levels of PTH in uremia are responsible for an increase in the calcium content of many tissues such as skin (23), cornea (24), blood vessels (25), muscle (26), brain $(27,28)$, and peripheral nerves (29). PTH apparently exerts a similar effect on the heart. Kraikipanitch et al. (30) demonstrated that calcium content of the myocardium is increased in uremic dogs with intact parathyroid glands and that

\footnotetext{
${ }^{1}$ Abbreviations used in this paper: $\mathrm{PTH}$, parathyroid hormone; PTX, parathyroidectomized; SR, sarcoplasma reticulum.
} 
parathyroidectomy prevented the accumulation of calcium in the heart of the uremic animals.

Excessive accumulation of calcium into the myocardial cells could be harmful to their functional integrity. Indeed, it has been shown that enhanced entry of calcium by catecholamines into cardiac cells can cause necrosis (31). It is therefore possible that the elevated blood levels of PTH in uremia may adversely affect myocardial function by augmenting calcium entry into the cardiac cells, and in such a manner participate in the overall pathogenesis of the uremic myocardiopathy. The present study was undertaken to examine the effects of PTH on the heart and to investigate the pathways through which PTH interacts with the myocardium.

\section{METHODS}

A large body of evidence has accumulated indicating that heart cells in culture represent normally functioning muscle cells (32). The use of heart cells in culture is therefore an appropriate tool for the study of the effect of various agents on the myocardium. Rat heart cells were grown into tissue culture according to the method of Harary and Farley (33). Wistar rats, 1-4 d old, were decapitated. Their hearts were removed under aseptic conditions and were placed in cold Dulbecco's phosphate-buffered saline (PBS) containing antibiotics. After all the hearts were rinsed, they were transferred to a new petri dish containing PBS and were minced into fragments $<1 \mathrm{~mm}$. The mince was transferred to a flask containing a magnetic bar and enough solution of $0.1 \%$ Viokase (VioBin Corp., Monticello, Ill.). Dissociation of the heart cells was achieved by incubation at $37^{\circ} \mathrm{C}$ while stirring for 20 min with a magnetic stirrer. All fragments were allowed to settle, and the supernate, which contained erythrocytes, endothelial cells, and some heart cells, was discarded. A new solution of Viokase was added, and the heart fragments were again incubated with stirring for $20 \mathrm{~min}$. The cell suspension was decanted into chilled sterile screwcap test tubes and kept in ice for $5 \mathrm{~min}$. It was then centrifuged at $1,000 \mathrm{~g}$ for $5 \mathrm{~min}$. The dissociation cycle, including incubation and stirring in $0.1 \%$ Viokase solution and centrifugation, was repeated for 4-5 times. The cell pellet was then suspended in complete growth medium made of CMRL (Connaught Medical Research Laboratories, Willodale, Ontario, Canada) supplemented with $5 \%$ horse serum and $5 \%$ fetal calf serum. The preparation of the cells by preferential attachment eliminates a high percentage of fibroblast, and $>80 \%$ of the cells are myocytes. Cells obtained from hearts of 1-4-d-old rats contain 45-60\% myocytes (nondividing cells) and the rest myoblasts (dividing cells) (34). The viability of the cells was ascertained by trypan blue exclusion method, and $>95 \%$ of the cells were viable.

Heart cells were counted with Coulter Counter-Electrozone Celloscope (Particle Data Inc., Elmhurst, Ill.), and $1.2 \times 10^{6}$ cells were plated on sterile dishes with $4 \mathrm{ml}$ of complete growth medium. The cells were then grown in an incubator at $37^{\circ} \mathrm{C}$ for $2 \mathrm{~d} .2 \mathrm{~h}$ prior to the study of the experimental condition, the old medium was replaced with a fresh one. The frequency of the beating of the heart cells was determined by direct counting, using a stopwatch and an inverted microscope. The time required for 10 beats was determined, and such measurements were repeated 2-4 times; the average was used to calculate the frequency of contraction in beats per minute.

\section{Effect of PTH}

The effects of both synthetic 1-34 fragment of PTH (1-34 PTH) (Beckman Instruments Inc., Spinco Div., Palo Alto, Calif.) and of purified bovine intact hormone molecule, 1-84 bPTH (Sigma Chemical Co., St. Louis, Mo.), were examined. Solutions of PTH were made by dissolving the hormone in distilled water. Preliminary studies showed that both moieties of PTH increase the frequency of beats per minute; therefore, the following studies were performed to delineate the interaction between the hormone and the cardiac cells.

Dose-response relationships. The effects of various concentrations of the hormone were examined to determine a dose-response curve and to find the optimal amount of PTH producing the maximum effect. Concentrations of $1,2.5,5$, 10,20 , and $60 \mathrm{U}$ of $1-34 \mathrm{PTH} / \mathrm{ml}$ medium and of $2,5,10,20$, 40 , and $60 \mathrm{U}$ of $1-84 \mathrm{bPTH} / \mathrm{ml}$ medium were used. For each dose level, five to six studies were performed, and the maximum effect during the first $5 \mathrm{~min}$ after the addition of PTH to the medium containing $1.3 \mathrm{mM}$ calcium was determined. It was found that $5 \mathrm{U}$ of $1-34 \mathrm{PTH} / \mathrm{ml}$ medium and $40 \mathrm{U}$ of $1-84 \mathrm{bPTH} / \mathrm{ml}$ medium exert the maximum effects. These amounts were used in all of the studies thereafter. In addition, the effect of 53-84 human PTH (Bachem Inc., Marina Del Rey, Calif.) was studied; $1.2 \mu \mathrm{g}$ of this preparation is equivalent to $10 \mathrm{U}$ of 1-84 bPTH.

Rapidity with which the effect of PTH occurs. The effects of both PTH moieties were examined every $30 \mathrm{~s}$ during the first $2 \mathrm{~min}$ after the addition of the hormone to the medium in five to seven studies.

Long-term effect of PTH. The effects of 1-34 PTH and 1-84 bPTH on the beating of the heart cells were examined at frequent intervals up to $51 \mathrm{~h}$ after the addition of the hormone to the medium. Studies were carried out in parallel with and without the hormone. In the studies without PTH, only the vehicle (distilled water) was added to the medium. The heart cells used in each experiment were obtained from the same heart cell population.

Reversibility of the effect of PTH. In four studies, 1-84 bPTH was added to the medium and the beating rate of the heart cells was determined $0.5,1,2,3$, and 5 min after the addition of the hormone. The medium was then changed with a fresh one containing no PTH and the beating rate was measured 10 min later. 1-84 bPTH was then added and the beating rate was again evaluated $0.5,1,2,3$, and 5 min thereafter.

Effect of inactivated PTH. 1-34 and 1-84 bPTH were inactivated as follows: $10-15 \mu \mathrm{g}$ of PTH was dissolved in $60 \mu \mathrm{l} 0.15 \mathrm{~N}$ acetic acid, and to this solution $40 \mu \mathrm{l}$ of $30 \%$ vol/vol $\mathrm{H}_{2} \mathrm{O}_{2}$ was added. The solution was incubated at $37^{\circ} \mathrm{C}$ for $45 \mathrm{~min}$, and reaction was terminated by freezing and lyophilizing. The effects of inactivated $5 \mathrm{U} / \mathrm{ml} \mathrm{1-34} \mathrm{PTH}$ and $40 \mathrm{U} / \mathrm{ml} \mathrm{1-84}$ bPTH were examined.

Effect of PTH on cyclic AMP production by heart cells. Cyclic AMP production by heart cells was measured before and $0.5,1,2,5,10,20,30$, and $60 \mathrm{~min}$ after the addition of 1-34 PTH to the medium. At the end of each interval in separate studies, the medium was decanted and the plastic petri dishes were placed on ice. The cells were then denatured with ice-cold $10 \%$ trichloroacetic acid and scraped from the dishes. The suspension was centrifuged at $3,000 \mathrm{~g}$ for 15 min using Sorval refrigerated centrifuge (DuPont Instruments, Newtown, Conn.). Determinations of cyclic AMP in the supernate were made by radioimmunoassay (35). The precipitate was dissolved in $1 \mathrm{~N} \mathrm{NaOH}$, and protein content was determined by the method of Lowry et al. (36). Two experiments, consisting of three studies for each interval of incubation, were performed, for a total of 51 studies. 
Effect of various concentrations of calcium in medium on the action of PTH. The influence of various concentrations of calcium in the medium $(0.2,0.4,0.6$, and $1.3 \mathrm{mM})$ on the effect of PTH on the beating rate of the heart cells was examined. 10 studies were performed at each calcium concentration; in 5 of the studies, 1-84 bPTH was added to the medium, whereas the other 5 studies served as control and only vehicle was added to the medium. To prepare lowcalcium media, calcium-free CMRL was supplemented with dialyzed horse and fetal calf sera. The calcium concentration of the mixture was determined and adequate amounts of calcium chloride were added to the medium to obtain the required concentration of calcium. The latter was ascertained by direct measurement as well.

\section{Effect of catecholamines and their interaction with PTH}

After determining the base-line values of the beating rate of the heart cells, five sets of studies were performed. First, either $\alpha$ - or $\beta$-adrenergic agents (phenylephrine or isoproterenol, respectively) were added to the medium to provide a concentration of $10-20 \mu \mathrm{M}$ and the beating rates were measured at $0.5,1,2,3$, and 5 min thereafter. Preliminary studies showed that these concentrations of the agonists produced maximum stimulation of the beating rate of the heart cells. 1-84 bPTH was then added and the beating rates were determined at $0.5,1,2,3$ and 5 min after the addition of the hormone. In a second set of similar studies, 1-84 bPTH was added first to the medium, followed by the $\alpha$ - or $\beta$-adrenergic agents. In the third and fourth sets of studies, the effect of $\alpha$ - or $\beta$ adrenergic blockers (phenoxybenzamine and propranolol, respectively) in a concentration of $10-20 \mu \mathrm{M}$ and their interaction with 1-84 bPTH were examined. Finally, studies were performed to examine whether PTH and catecholamines have a synergistic effect on the beating rates of the heart cells. In these studies, suboptimal doses of $1-84 \mathrm{bPTH}(20 \mathrm{U} / \mathrm{ml}$ medium) and of catecholamines $(5 \mu \mathrm{M})$ were used. The effects of PTH alone, catecholamines alone, and those of both together were evaluated in parallel studies, using the same heart cells population.

\section{Effect of A23187 calcium ionophore and its interaction with PTH}

The A23187 calcium ionophore (kindly supplied by Eli Lilly \& Co., Indianapolis, Ind.) was dissolved in dimethylsulfoxide and diluted 1:10 with complete growth media. After determining the base-line values of the beating rate, two sets of studies were performed. First, the ionophore was added to the medium to provide a concentration of $1 \mu \mathrm{M}$, and the beating rate was determined at $1,2,3$, and $5 \mathrm{~min}$ after the addition of the hormone. In the second set of studies, 1-84 bPTH was added first to the medium, followed by ionophore.

In addition, parallel studies were performed, using the same heart cell population, in which either 1-84 bPTH or ionophore alone or both agents together were added to the culture medium.

\section{Effect of verapamil and its interaction with PTH}

Studies similar to those described with calcium ionophore above were performed using verapamil (Isoptene, Knoll AG, Ludwigschagen, Germany) in a concentration of $0.2 \mu \mathrm{M}$. In the first set of studies, the verapamil was added first to the culture medium, followed by $1-84 \mathrm{bPTH}$; the sequence was reversed in the second set of studies.

\section{Effect of uremic sera on heart cells}

The effects of uremic sera with and without PTH on the beating rate of the heart cells were examined. Acute uremia was produced by bilateral nephrectomy in intact and parathyroidectomized (PTX) Wistar rats weighing $250 \mathrm{~g}$. Parathyroidectomy was produced with cautery and the success of the procedure was ascertained by a drop in the level of serum calcium of at least $2.0 \mathrm{mg} / \mathrm{dl}$. A group of PTX-nephrectomized rats received intraperitoneal injections of $20 \mathrm{U}$ of 1-84 bPTH twice daily beginning after nephrectomy and until they were killed. All rats were bled $48 \mathrm{~h}$ after nephrectomy and sera were prepared. Sera from control rats and from those with uremia replaced the horse serum in the complete growth medium used in these studies. Thus, the medium was made of CMRL supplemented with $10 \%$ of the appropriate rat serum and $5 \%$ fetal calf serum.

The heart cells were grown in the usual complete growth medium. The basal value of the beating rate was determined and then the medium was changed to the experimental one. In each of the experiments, parallel studies on heart cells of the same population were performed with the medium containing serum, either from normal rats, uremic rats with intact parathyroid glands, PTX-uremic rats, or PTX-uremic rats treated with PTH. The beating rate of the heart cells was evaluated at various intervals up to $30 \mathrm{~h}$.

\section{Statistical analysis}

The $t$ test was used for the statistical analysis of the data.

\section{RESULTS}

The effects of 1-34 and 1-84 bPTH on the beating of the heart cells are shown in Figs. 1 and 2 and Table I. Both moieties of PTH produced significant increments

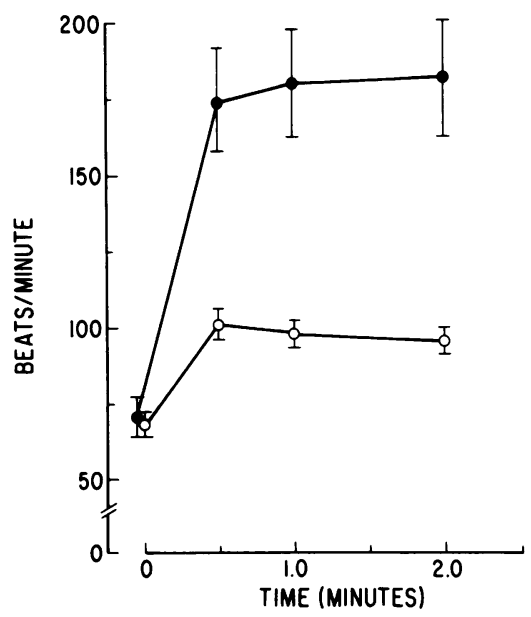

Figure 1 The effect of the intact molecule of PTH (1-84 PTH) and its amino-terminal fragment (1-34 PTH) on beating rates of heart cells in relation to time, after the addition of the hormone to medium containing the heart cells. $\bullet, 1-84$ PTH; O, 1-34 PTH. 


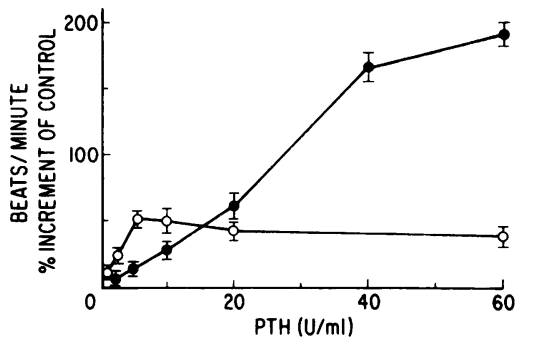

Figure 2 Dose-response curves for the effects of the intact molecules of PTH (1-84 PTH) and its amino-terminal fragment (1-34 PTH) on the beating rates of the heart cells. 1-84 PTH; O, 1-34 PTH.

in the beating rate within $30 \mathrm{~s}$ of their addition to the medium (Fig. 1), and this effect lasted for at least 12-24 h (Table I). Thereafter, the beating rates of the cells in the medium containing PTH was significantly lower than that of the control cells, and the PTHtreated cells ceased to beat earlier than the control ones (Table I). There was a dose-response relationship between both 1-34 and 1-84 bPTH and their effects on the beating rate. It is of interest that the effect of $1-84$ bPTH was significantly $(P<0.01)$ smaller than that of 1-34 PTH at the lower doses $(2-5 \mathrm{U} / \mathrm{ml}$ medium) and significantly $(P<0.01)$ greater at the higher doses (40-60 $\mathrm{U} / \mathrm{ml}$ medium). The maximum increments in beating rate induced by $1-34 \mathrm{PTH}$ were $53 \pm 3.8 \%$ (SE) and was achieved with $5 \mathrm{U} / \mathrm{ml}$ medium while the maximum increments with 1-84 bPTH were obtained with $40-60 \mathrm{U} / \mathrm{ml}$ medium. The carboxy-terminal (5384) PTH in concentration of $1-16 \mu \mathrm{g} / \mathrm{ml}$ did not stimulate the beating of the heart cells (Table II). Inactivation of 1-34 and 1-84 bPTH abolished their effects (Table II).

The effect of 1-84 bPTH on the heart cells was reversible, and the stimulation of beating rate disappeared after removal of PTH from the medium, with beats per minute $(113 \pm 2.1)$ returning almost to the initial basal value (102 \pm 1.7$)$. A second addition of 1-84 bPTH to the same cells incubated in fresh medium produced a stimulation of beating rate comparable to that observed during the first addition of the hormone (Table III).

The effect of 1-34 PTH on cyclic AMP production by the heart cells is shown in Fig. 3. There was a marked and significant $(P<0.01)$ increment in cyclic AMP production by the heart cells within $30 \mathrm{~s}$ of the

TABLE I

Effect of PTH on the Beating of Heart Cells

\begin{tabular}{|c|c|c|c|c|c|c|c|c|c|c|}
\hline Study $1^{*}$ & & & & & & & & & & \\
\hline Time, $h$ & 0 & 1 & 2 & 4 & 6 & 8 & 21 & 45 & & \\
\hline \multicolumn{11}{|l|}{ Beats/min } \\
\hline Control & $135 \pm 2.7$ & $129 \pm 4.4$ & $122 \pm 1.7$ & $108 \pm 2.1$ & $102 \pm 2.2$ & $86 \pm 0.6$ & $50 \pm 2.2$ & $30 \pm 1.8$ & & \\
\hline РТН & $137 \pm 3.8$ & $149 \div 2.2$ & $143 \pm 2.4$ & $125 \pm 2.9$ & $117 \pm 3.2$ & $102 \pm 1.2$ & $63 \pm 2.1$ & No beating & & \\
\hline \multicolumn{11}{|l|}{ Relative activity } \\
\hline PTH, \% of control & $102 \pm 2.8$ & $116 \pm 1.7$ & $117 \pm 2.0$ & $118 \pm 2.9$ & $116 \pm 3.2$ & $119 \pm 1.4$ & $127 \pm 4.3$ & & & \\
\hline$P$ PTH vs. control & NS & $<0.01$ & $<0.01$ & $<0.01$ & $<0.01$ & $<0.01$ & $<0.01$ & & & \\
\hline \multicolumn{11}{|l|}{ Study $2^{*}$} \\
\hline Time, $h$ & 0 & 2 & 6 & 21 & 27 & 51 & & & & \\
\hline \multicolumn{11}{|l|}{ Beats/min } \\
\hline Control & $95 \pm 1.4$ & $99 \pm 1.3$ & $89 \pm 0.7$ & $66 \pm 0.5$ & $5.3 \pm 0.8$ & $30 \pm 0.9$ & & & & \\
\hline PTH & $93 \pm 1.3$ & $107 \pm 1.3$ & $112 \pm 1.0$ & $81 \pm 1.2$ & $70 \pm 1.1$ & No beating & & & & \\
\hline \multicolumn{11}{|l|}{ Relative activity } \\
\hline PTH, \% of control & $98 \pm 1.4$ & $108+1.3$ & $125 \pm 1.1$ & $124 \pm 1.8$ & $132 \pm 2.1$ & & & & & \\
\hline$P$ PTH vs. control & NS & $<0.01$ & $<0.01$ & $<0.01$ & $<0.01$ & & & & & \\
\hline \multicolumn{11}{|l|}{ Study $3 \ddagger$} \\
\hline Time, $h$ & 0 & 1 & 2 & 3 & 5 & 8 & 12 & 24 & 30 & 36 \\
\hline \multicolumn{11}{|l|}{ Beats/min } \\
\hline Control & $101 \pm 1.3$ & $102 \pm 1.0$ & $104 \pm 1.4$ & $98 \pm 0.5$ & $95 \pm 2.1$ & $90 \pm 2.2$ & $85 \pm 4.1$ & $72 \pm 3.2$ & $62 \pm 2.9$ & $46 \pm 1.4$ \\
\hline PTH & $101 \pm 1.7$ & $184 \pm 6.7$ & $175 \pm 8.5$ & $169 \pm 3.0$ & $167 \pm 7.4$ & $152 \pm 3.7$ & $138 \pm 4.5$ & $60 \pm 3.8$ & $36 \pm 1.7$ & No beating \\
\hline \multicolumn{11}{|l|}{ Relative activity } \\
\hline PTH, \% of control & $100 \pm 1.7$ & $180 \pm 6.5$ & $168 \pm 8.2$ & $17.3 \pm 3.1$ & $176 \pm 7.8$ & $169 \pm 4.1$ & $162 \pm 5.3$ & $8.3 \pm 5.3$ & $58 \pm 2.7$ & \\
\hline$P$ PTH vs. control & NS & $<0.01$ & $<0.01$ & $<0.01$ & $<0.01$ & $<0.01$ & $<0.01$ & $<0.01$ & $<0.01$ & \\
\hline \multicolumn{11}{|l|}{ Study $4 \rrbracket$} \\
\hline Time, $h$ & 0 & 1 & 2 & 3 & 6 & 12 & 24 & 30 & 36 & \\
\hline \multicolumn{11}{|l|}{ Beats/min } \\
\hline Control & $107 \pm 3.4$ & $109 \pm 3.6$ & $105+4.0$ & $106+3.6$ & $98 \pm 2.2$ & $96 \pm 2.2$ & $63 \pm 2.8$ & $51 \pm 2.5$ & $31 \pm 1.7$ & \\
\hline РТн & $107 \pm 2.5$ & $191 \pm 3.3$ & $189 \pm 4.1$ & $185 \pm 4.9$ & $182 \pm 3.8$ & $1.38 \pm 6.5$ & $54 \pm 3.1$ & $31 \pm 3.2$ & No beating & \\
\hline \multicolumn{11}{|l|}{ Relative activity } \\
\hline PTH, \% of control & $100 \pm 2.3$ & $175 \pm 3.0$ & $180 \pm 3.9$ & $175 \pm 4.6$ & $186 \pm 3.9$ & $144 \pm 6.8$ & $86 \pm 4.9$ & $61 \pm 6.3$ & & \\
\hline$P$ PTH vs. control & NS & $<0.01$ & $<0.01$ & $<0.01$ & $<0.01$ & $<0.01$ & $<0.05$ & $<0.01$ & & \\
\hline
\end{tabular}

Data are presented as mean $\pm \mathrm{SE}$.

* Studies 1 and 2 examined the effect of 1-34 PTH (study $1, n=5$; study 2, $n=5$ ).

1 Studies 3 and 4 examined the effect of 1-84 PTH (study $3, n=5$; study $4, n=6$ ). 
TABLE II

Effect of Inactivation of 1-84 and 1-34 PTH and the Effect of 53-84 PTH on the Beating Rate of Heart Cells

\begin{tabular}{|c|c|c|c|c|c|c|c|c|}
\hline \multirow[b]{2}{*}{ Treatment } & \multicolumn{8}{|c|}{ Time (min) } \\
\hline & 0 & 0.5 & 1.0 & 2.0 & 3.0 & 5.0 & $0.5^{*}$ & $1.0^{*}$ \\
\hline & \multicolumn{8}{|c|}{ beats/min } \\
\hline $1-84 \mathrm{bPTH}(40 \mathrm{U} / \mathrm{ml})$ & $103 \pm 2.1$ & $180 \pm 4.2$ & $186 \pm 3.6$ & $190 \pm 4.1$ & $193 \pm 2$ & $195 \pm 3.2$ & & \\
\hline Inactivated $(40 \mathrm{U} / \mathrm{ml})$ & $104 \pm 2.2$ & $105 \pm 3.1$ & $104 \pm 2.4$ & $107 \pm 3.2$ & $105 \pm 2.5$ & $107 \pm 2.1$ & & \\
\hline 1-34 РТН (5 U/ml) & $98 \pm 3.1$ & $135 \pm 4.2$ & $140 \pm 3.6$ & $143 \pm 3.5$ & $145 \pm 41$ & $144 \pm 3.1$ & & \\
\hline Inactivated $(5 \mathrm{U} / \mathrm{ml})$ & $100 \pm 2.4$ & $98 \pm 2.2$ & $101 \pm 2.1$ & $99 \pm 2.6$ & $102 \pm 3.7$ & $100 \pm 4.1$ & & \\
\hline \multicolumn{9}{|l|}{ 53-84 РТН } \\
\hline $1.0 \mu \mathrm{g} / \mathrm{ml}$ & $127 \pm 4.1$ & $130 \pm 3.7$ & $128 \pm 4.1$ & $132 \pm 3.6$ & $129 \pm 4.1$ & $125 \pm 4.1$ & & \\
\hline $2.0 \mu \mathrm{g} / \mathrm{ml}$ & $115 \pm 3.2$ & $118 \pm 4.1$ & $113 \pm 3.2$ & $116 \pm 4.1$ & $115 \pm 3.2$ & $117 \pm 2.1$ & & \\
\hline $4.0 \mu \mathrm{g} / \mathrm{ml}$ & $120 \pm 4.2$ & $125 \pm 5.1$ & $123 \pm 4.1$ & $126 \pm 3.6$ & $120 \pm 4.2$ & $122 \pm 3.4$ & & \\
\hline $16.0 \mu \mathrm{g} / \mathrm{ml}$ & $118 \pm 4.6$ & $123 \pm 3.6$ & $120 \pm 5.1$ & $124 \pm 5.2$ & $125 \pm 3.7$ & $123 \pm 4.1$ & $210 \pm 3.2$ & $215 \pm 4.1$ \\
\hline
\end{tabular}

Data are presented as mean $\pm \mathrm{SE}$ of three to five studies.

* Denotes elapsed time after addition of 1-84 bPTH (40 U/ml).

addition of the hormone to the medium. In one experiment, it increased from $4.27 \pm 0.24$ to $15.7 \pm 1.6$ $\mathrm{pmol} / \mathrm{mg}$ protein, and in the second experiment from $5.4 \pm 0.6$ to $11.2 \pm 0.3 \mathrm{pmol} / \mathrm{mg}$ protein. Cyclic AMP production fell subsequently, but remained significantly $(P<0.01-0.05)$ higher than base-line levels for the entire 60 min of the study.

The effects of different concentrations of calcium in the medium on the heart cells and on the action of PTH are given in Table IV. The basal beating rate of the heart cells was calcium dependent. It was lowest at

TABLE III

Reversibility of the Effect of PTH

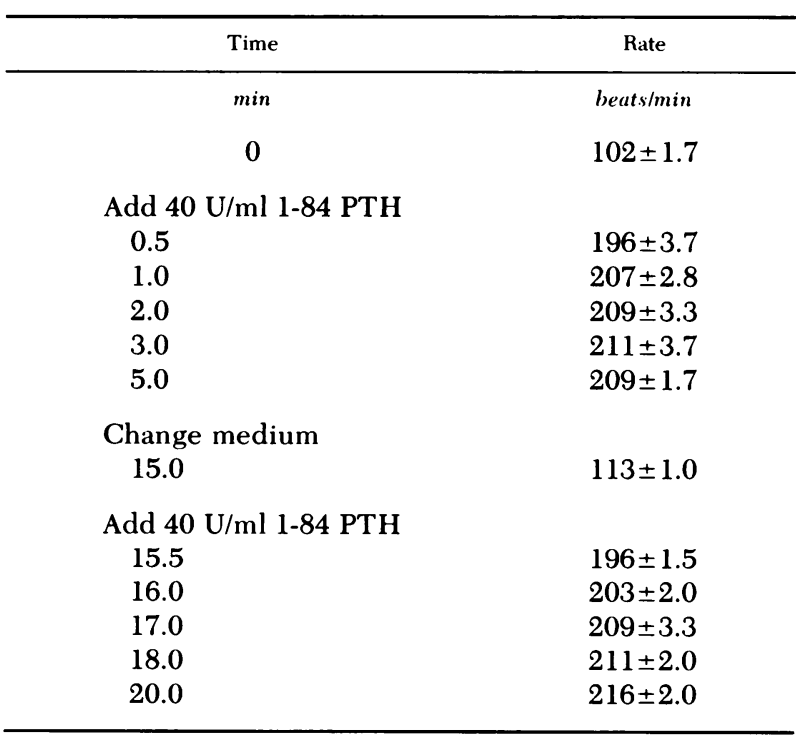

Each datum is the mean $\pm \mathrm{SE}$ of four studies.
$0.2 \mathrm{mM}$ calcium and highest at $1.3 \mathrm{mM}$ calcium. Addition of 1-34 PTH produced significant $(P<0.01)$ increments in beating rate at all concentrations of calcium. It is interesting that the highest percent increment in the beating rate with PTH occurred at the lowest calcium concentration $(0.2 \mathrm{mM})$. The beating rate at a lower calcium concentration in the presence of PTH was not different from that observed with the next higher calcium concentration, but without PTH - as if PTH magnified the concentration of calcium.

Summary of all studies on the effect of $\alpha$ - and $\beta$ adrenergic agents and blockers, and on their inter-

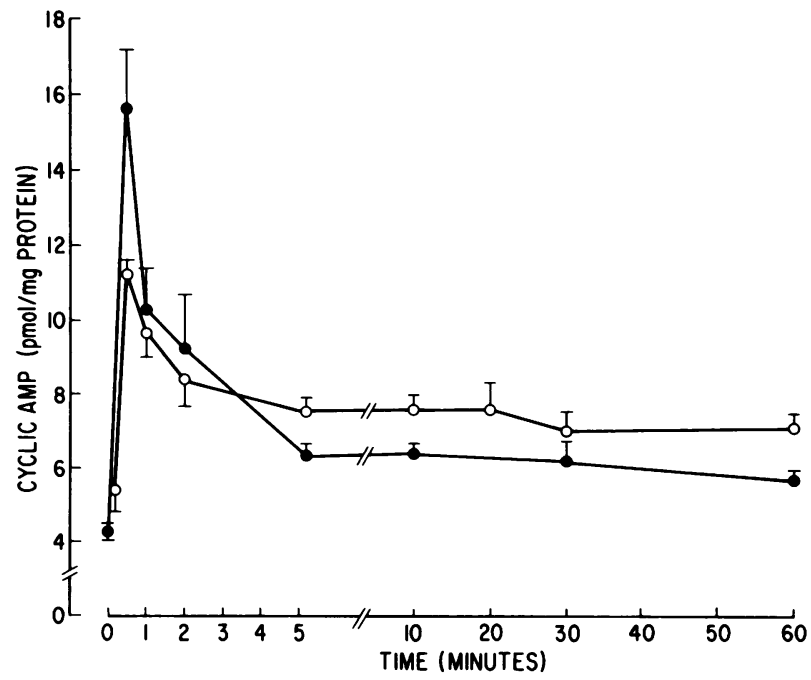

FIGURE 3 The effect of 1-34 PTH on cyclic AMP production by heart cells. Each line represents one experiment and each point denotes the mean $\pm S E$ of three studies. 
TABLE IV

Effects of Various Concentrations of Calcium in Medium on the Action of 1-34 PTH on Heart Cells

\begin{tabular}{|c|c|c|c|c|c|c|c|c|}
\hline \multirow[b]{2}{*}{ Time } & \multicolumn{2}{|c|}{$0.2 \mathrm{mM} \mathrm{Ca}$} & \multicolumn{2}{|c|}{$0.4 \mathrm{mM} \mathrm{Ca}$} & \multicolumn{2}{|c|}{$0.6 \mathrm{mM} \mathrm{Ca}$} & \multicolumn{2}{|c|}{$1.3 \mathrm{mM} \mathrm{Ca}$} \\
\hline & -PTH & + PTH & - РTH & + PTH & -PTH & + PTH & -PTH & $+\mathrm{PTH}$ \\
\hline $\min$ & \multicolumn{8}{|c|}{ beats/min } \\
\hline 0 & $33 \pm 7.2$ & $37 \pm 1.2$ & $58 \pm 4.2$ & $56 \pm 3.1$ & $73 \pm 3.8$ & $78 \pm 3.3$ & $110 \pm 4.1$ & $107 \pm 2.1$ \\
\hline $\begin{array}{c}\text { Add } 1-34 \text { PTH } \\
5\end{array}$ & $33 \pm 7.2$ & $60 \pm 1.1$ & $58 \pm 4.2$ & $76 \pm 2.4$ & $76 \pm 3.8$ & $101 \pm 1.0$ & $110 \pm 4.1$ & $129 \pm 2.2$ \\
\hline
\end{tabular}

Each datum is the mean $\pm \mathrm{SE}$ of five studies. $+/-$, with/without.

action of 1-84 bPTH are given in Tables V and VI, and representative studies are depicted in Fig. 4. Both $\alpha$ - and $\beta$-adrenergic agonists produced significant $(P<0.01)$ stimulation of the beating rate of the heart cells. These effects occurred within $30 \mathrm{~s}$ and plateaued thereafter. Addition of 1-84 bPTH to those already stimulated heart cells produced within $30 \mathrm{~s}$ further significant $(P<0.01)$ stimulation of the beating rate. These additive effects were also demonstrable when the sequence of addition of adrenergic agonists and PTH to the medium was reversed. Both $\alpha$ - and $\beta$ adrenergic blockers did not affect the stimulation of

TABLE V

Effects of $\alpha$-and $\beta$-Adrenergic Agonists and Blockers and Their Interaction with PTH on the Beating Rate of the Heart Cells

\begin{tabular}{|c|c|c|c|c|}
\hline Elapsed time & PTH $(n=6)$ & $\begin{array}{l}\text { Phenylephrine } \\
(\alpha)(n=6) \\
\text { or isoproterenol } \\
(\beta)(n=6)\end{array}$ & PTH $(n=7)$ & $\begin{array}{l}\text { Phenoxybenzamine } \\
\qquad \alpha)(n=7) \\
\text { or propranolol } \\
(\beta)(n=6)\end{array}$ \\
\hline $\min$ & & & eats/min & \\
\hline \multicolumn{5}{|c|}{ I. PTH and $\alpha$-adrenergic system } \\
\hline 0 & $62 \pm 3.5$ & $58 \pm 3.6$ & $66 \pm 4.7$ & $62 \pm 3.4$ \\
\hline 0.5 & $97 \pm 5.0$ & $85 \pm 3.9$ & $111 \pm 10.4$ & $63 \pm 3.5$ \\
\hline 1.0 & $104 \pm 6.0$ & $82 \pm 3.9$ & $116 \pm 10.7$ & $62 \pm 2.9$ \\
\hline 2.0 & $118 \pm 10.8$ & $83 \pm 4.7$ & $125 \pm 12.0$ & $60 \pm 3.2$ \\
\hline 3.0 & $121 \pm 11.7$ & $86 \pm 4.5$ & $130 \pm 11.2$ & $58 \pm 3.1$ \\
\hline \multirow[t]{2}{*}{5.0} & $121 \pm 12.1$ & $85 \pm 3.7$ & $137 \pm 11.8$ & $56 \pm 3.5$ \\
\hline & Add phenylephrine & Add PTH & Add phenoxybenzamine & Add PTH \\
\hline 0.5 & $171 \pm 15.0$ & $146 \pm 9.8$ & $143 \pm 12.6$ & $104 \pm 11.3$ \\
\hline 1.0 & $176 \pm 14.8$ & $153 \pm 10.7$ & $143 \pm 11.0$ & $110 \pm 11.3$ \\
\hline 2.0 & $178 \pm 13.4$ & $165 \pm 7.1$ & $136 \pm 11.0$ & $122 \pm 9.7$ \\
\hline 3.0 & $180 \pm 12.0$ & $171 \pm 9.3$ & $132 \pm 12.1$ & $129 \pm 7.3$ \\
\hline 5.0 & $178 \pm 12.0$ & $171 \pm 8.8$ & $128 \pm 12.9$ & $130 \pm 6.2$ \\
\hline \multicolumn{5}{|c|}{ II. PTH and $\beta$-adrenergic system } \\
\hline 0 & $69 \pm 4.6$ & $64 \pm 3.8$ & $69 \pm 2.3$ & $69 \pm 2.4$ \\
\hline 0.5 & $109 \pm 7.9$ & $93 \pm 10.5$ & $113 \pm 2.5$ & $69 \pm 4.2$ \\
\hline 1.0 & $115 \pm 9.0$ & $97 \pm 12.0$ & $121 \pm 3.5$ & $68 \pm 3.9$ \\
\hline 2.0 & $117 \pm 9.3$ & $93 \pm 9.9$ & $128 \pm 3.3$ & $66 \pm 3.6$ \\
\hline 3.0 & $114 \pm 8.8$ & $89 \pm 8.8$ & $133 \pm 4.2$ & $64 \pm 3.2$ \\
\hline \multirow[t]{2}{*}{5.0} & $113 \pm 8.9$ & $89 \pm 8.8$ & $140 \pm 5.6$ & $62 \pm 3.5$ \\
\hline & Add isoproterenol & Add PTH & Add propranolol & Add PTH \\
\hline 0.5 & $181 \pm 10.7$ & $160 \pm 13.6$ & $145 \pm 5.5$ & $100 \pm 3.9$ \\
\hline 1.0 & $185 \pm 10.8$ & $171 \pm 14.6$ & $142 \pm 5.1$ & $101 \pm 3.5$ \\
\hline 3.0 & $183 \pm 10.6$ & $182 \pm 12.2$ & $133 \pm 5.6$ & $107 \pm 4.1$ \\
\hline 5.0 & $186 \pm 8.5$ & $178 \pm 10.9$ & $128 \pm 4.8$ & $107 \pm 4.0$ \\
\hline
\end{tabular}

Data are presented as mean \pm SE. The PTH used was 1-84 PTH (Sigma) in a concentration of $40 \mathrm{U} / \mathrm{ml}$. The concentrations of phenylephrine, phenoxybenzamine, isoproterenol, or propranolol were $10-20 \mu \mathrm{M}$. 
TABLE VI

Effects of PTH and Adrenergic Agonists on Heart Cells When These Compounds Were Added to the Medium Alone or Together

\begin{tabular}{lccccc}
\hline \multicolumn{5}{c}{ Increase in beating rate from base-line values } \\
\cline { 2 - 6 } Time & $\begin{array}{c}\text { PTH } \\
\text { alone }\end{array}$ & $\begin{array}{c}\text { Isoproterenol } \\
\text { alone }\end{array}$ & $\begin{array}{c}\text { PTH plus } \\
\text { isoproterenol }\end{array}$ & $\begin{array}{c}\text { Phenylephrine } \\
\text { alone }\end{array}$ & $\begin{array}{c}\text { PTH plus } \\
\text { phenylephrine }\end{array}$ \\
\hline $\min$ & & & & \\
0.5 & $31 \pm 3.6$ & $19 \pm 2.8$ & $103 \pm 21.7$ & $22 \pm 2.9$ & $65 \pm 2.3$ \\
1.0 & $36 \pm 4.3$ & $12 \pm 2.3$ & $112 \pm 22.4$ & $22 \pm 2.5$ & $62 \pm 3.2$ \\
2.0 & $44 \pm 5.9$ & $12 \pm 1.3$ & $111 \pm 20.3$ & $24 \pm 2.8$ & $72 \pm 7.1$ \\
3.0 & $50 \pm 7.1$ & $10 \pm 2.4$ & $120 \pm 18.6$ & $27 \pm 2.6$ & $79 \pm 5.4$ \\
5.0 & $54 \pm 8.2$ & $11 \pm 1.6$ & $119 \pm 19.1$ & $31 \pm 3.0$ & $81 \pm 3.7$ \\
\hline
\end{tabular}

The PTH used was 1-84 in a concentration of $20 \mathrm{U} / \mathrm{ml}$ medium. The concentration of isoproterenol or phenylephrine was $5 \mu \mathrm{M}$. Each datum represents mean $\pm \mathrm{SE}$ of six studies.

the beating rate by $1-84 \mathrm{bPTH}$, whether the blockers were added to the medium before or after the addition of 1-84 bPTH.

The simultaneous addition of suboptimal doses of 1-84 bPTH and $\alpha$-adrenergic agonist (isoproterenol) produced significantly $(P<0.01)$ greater increments in beating rate than the sum of the increments obtained by PTH or isoproterenol alone (Table IV). In contrast, simultaneous addition of PTH and $\alpha$-adrenergic agonist (phenylephrine) did not produce greater stimulation of the beating rate than the sum of the stimulation produced by PTH and phenylephrine alone (Table VI).

The summary of the results of the studies on the interaction between PTH, calcium ionophore, and verapamil is given in Tables VII and VIII, and repre-

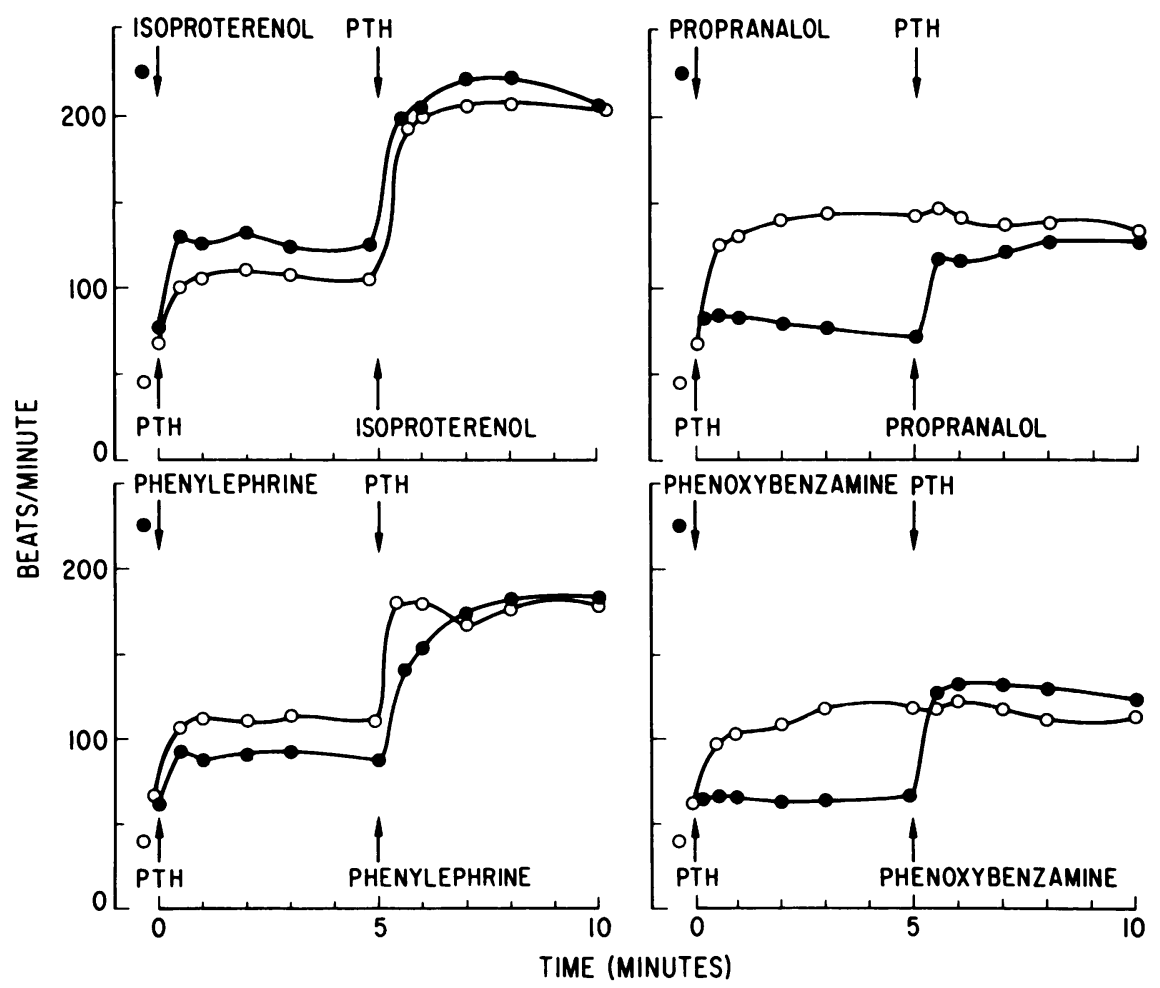

FIGURE 4 Representative studies depicting the interaction between PTH and $\alpha$-(phenylephrine) and $\beta$ - (isoproterenol) adrenergic agents and between PTH and $\alpha$ - (phenoxybenzamine) and $\beta$ (propranolol) adrenergic blockers and beating rates of heart cells. 
TABLE VII

Interaction between 1-84 PTH and Calcium Ionophore A23187 or Verapamil

\begin{tabular}{|c|c|c|}
\hline Time & $\operatorname{PTH}(n=5)$ & $\begin{array}{c}\text { A23187 }(n=4) \\
\text { or verapamil }(n=7)\end{array}$ \\
\hline $\min$ & beats/min & beats/min \\
\hline \multicolumn{3}{|c|}{ I. PTH and calcium ionophore } \\
\hline 0 & $71 \pm 3.6$ & $84 \pm 9.1$ \\
\hline 0.5 & $183 \pm 10.6$ & $192 \pm 18.8$ \\
\hline 1.0 & $191 \pm 9.9$ & $186 \pm 22.2$ \\
\hline 2.0 & $200 \pm 9.4$ & $188 \pm 21.0$ \\
\hline 3.0 & $204 \pm 8.4$ & $188 \pm 22.8$ \\
\hline \multirow[t]{2}{*}{5.0} & $202 \pm 9.1$ & $184 \pm 22.5$ \\
\hline & Add A23187 & Add PTH \\
\hline 0.5 & $218 \pm 6.2$ & $183 \pm 20.0$ \\
\hline 1.0 & $210 \pm 8.5$ & $193 \pm 19.6$ \\
\hline 2.0 & $200 \pm 12.1$ & $190 \pm 16.8$ \\
\hline 3.0 & $186 \pm 15.9$ & $192 \pm 16.0$ \\
\hline 5.0 & $168 \pm 20.1$ & $188 \pm 16.5$ \\
\hline \multicolumn{3}{|c|}{ II. PTH and verapamil } \\
\hline 0 & $61 \pm 6.4$ & $65 \pm 7.2$ \\
\hline 1.0 & $110 \pm 9.3$ & $50 \pm 4.1$ \\
\hline 2.0 & $112 \pm 8.8$ & $48 \pm 3.4$ \\
\hline 3.0 & $111 \pm 10.0$ & $45 \pm 3.1$ \\
\hline \multirow[t]{2}{*}{5.0} & $106 \pm 10.9$ & $41 \pm 2.8$ \\
\hline & Add verapamil & Add PTH \\
\hline 0.5 & $76 \pm 12.1$ & $34 \pm 9.6$ \\
\hline 1.0 & $63 \pm 11.9$ & $35 \pm 8.4$ \\
\hline 3.0 & $52 \pm 11.5$ & $35 \pm 9.0$ \\
\hline 5.0 & $42 \pm 10.5$ & $34 \pm 8.6$ \\
\hline
\end{tabular}

Data are presented as mean \pm SE. PTH used was 1-84 PTH in a concentration of $40 \mathrm{U} / \mathrm{ml}$. Concentration of calcium ionophore was $1 \mu \mathrm{M}$. Concentration of verapamil was $0.2 \mu \mathrm{M}$.

sentative experiments are depicted in Fig. 5. Calcium ionophore produced stimulation of the beating rate of the heart cells similar to that observed with 1-84 bPTH. The addition of calcium ionophore to cells already

TABLE VIII

Effects of PTH and Calcium Ionophore When These Compounds Were Added to the Medium Alone or Together

\begin{tabular}{lccr}
\hline & \multicolumn{3}{c}{ Heart rate } \\
\cline { 2 - 4 } Time & PTH alone & $\begin{array}{c}\text { Calcium } \\
\text { ionophore alone }\end{array}$ & $\begin{array}{c}\text { PTH plus } \\
\text { calcium ion }\end{array}$ \\
\hline min & & beats/min & \\
0 & $78 \pm 2.8$ & $85 \pm 7.1$ & $83 \pm 1.4$ \\
0.5 & $184 \pm 5.4$ & $186 \pm 15.7$ & $195 \pm 2.9$ \\
1.0 & $187 \pm 5.9$ & $180 \pm 18.1$ & $199 \pm 1.0$ \\
2.0 & $190 \pm 5.8$ & $177 \pm 19.8$ & $206 \pm 2.1$ \\
3.0 & $193 \pm 5.1$ & $177 \pm 20.8$ & $204 \pm 2.8$ \\
5.0 & $194 \pm 5.3$ & $184 \pm 22.5$ & $205 \pm 4.3$ \\
\hline
\end{tabular}

The PTH used was 1-84 in a concentration of $40 \mathrm{U} / \mathrm{ml}$ medium. The concentration of calcium ionophore was $1 \mu \mathrm{M}$. Each datum represents mean $\pm S E$ of five studies. stimulated by PTH produced no further stimulation of the beating rate. Further, the stimulation of the beating rate of the heart cells by PTH or calcium ionophore alone or together was not different (Table VIII).

Addition of verapamil to the medium was associated with gradual but significant decline in the beating rates of the heart cells. The subsequent addition of 1-84 bPTH to the medium already containing verapamil did not produce stimulation of heart cells. When verapamil was added to PTH-stimulated heart cells, the beating rate declined within $1 \mathrm{~min}$ to the original base-line values and continued to fall gradually during the ensuing $5 \mathrm{~min}$.

The effects of uremic sera with and without PTH on the beating rate of the heart cells are given in Table IX and Fig. 6. Uremic sera from nephrectomized rats with intact parathyroid glands produced significant $(P<0.05-0.01)$ stimulation of the beating rate for $12-20 \mathrm{~h}$. Thereafter, the beating rate started to decline and was significantly lower than that of the control cells. These observations are similar to those seen during the addition of either 1-34 or 1-84 bPTH to the medium (Table I). In contrast, uremic sera from 


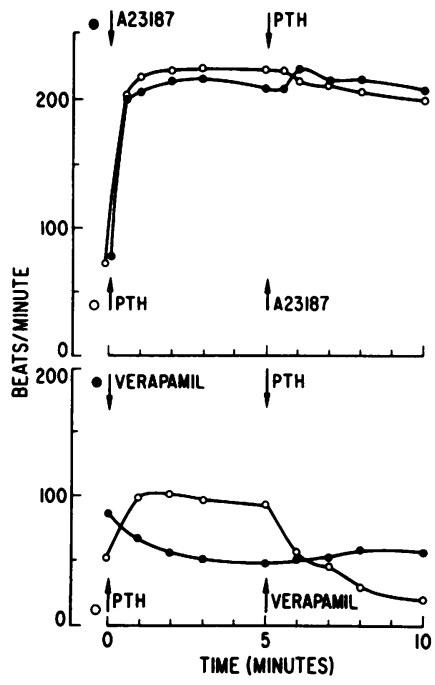

FIGURE 5 Representative studies on the interaction between PTH and calcium ionophore A23187 (upper panel) and PTH and verapamil (lower panel) on the beating rates of heart cells.
nephrectomized-PTX rats did not affect the beating rate of the heart cells; the beating of heart cells was similar in the presence of both control serum and serum from PTX-uremic rats. Finally, uremic serum obtained from PTX-uremic rats treated with 1-84 bPTH produced significant $(P<0.05-0.01)$ stimulation of the heart cells for 10-20 h, followed by slowing of the beating rate; these observations are similar to those noted after the addition of 1-34 or 1-84 bPTH or in the presence of serum from uremic rats with intact parathyroid glands.

\section{DISCUSSION}

The results of the present study demonstrate that both intact PTH and its amino-terminal fragment stimulated the frequency of the beating of the heart cells. This effect occurred almost immediately, continued for many hours as long as the hormone was present, was reversible, and was dose dependent. The demonstration that the inactivation of the PTH abolished its

TABLE IX

Effects of Uremic Sera with and without PTH on Beating Rate of Heart Cells

\begin{tabular}{|c|c|c|c|c|c|c|c|c|c|c|}
\hline Time & $\begin{array}{c}\text { Normal } \\
\text { serum }\end{array}$ & $\begin{array}{c}\mathrm{NX} \\
\text { serum }\end{array}$ & $\begin{array}{c}\text { Relative } \\
\text { activity } \\
\text { NX }\end{array}$ & $P$ & $\begin{array}{c}\text { PTX-NX } \\
\text { serum }\end{array}$ & $\begin{array}{c}\text { Relative } \\
\text { activity } \\
\text { PTX-NX }\end{array}$ & $P$ & $\begin{array}{c}\text { PTX-NX } \\
\text { (PTH) } \\
\text { serum }\end{array}$ & $\begin{array}{c}\text { Relative } \\
\text { activity } \\
\text { PTX-NX } \\
\text { (PTH) }\end{array}$ & $P$ \\
\hline$h$ & beats/min & beats/min & $\%$ control & & beats/min & $\%$ control & & beats/min & $\%$ control & \\
\hline \multicolumn{11}{|c|}{ Study $1(n=7)$} \\
\hline 0 & $108 \pm 4.1$ & $108 \pm 4.1$ & & & $107 \pm 4.1$ & & & $109 \pm 4.1$ & & \\
\hline 2 & $105 \pm 5.1$ & $122 \pm 4.4$ & $115 \pm 4.2$ & $<0.01$ & $104 \pm 3.8$ & $99 \pm 3.3$ & NS & $128 \pm 3.8$ & $121 \pm 3.8$ & $<0.01$ \\
\hline 3 & $104 \pm 3.6$ & $128 \pm 4.4$ & $123 \pm 4.4$ & $<0.01$ & $99 \pm 3.4$ & $95 \pm 3.3$ & NS & $128 \pm 4.4$ & $122 \pm 4.3$ & $<0.01$ \\
\hline 5 & $103 \pm 4.1$ & $123 \pm 3.8$ & $118 \pm 3.4$ & $<0.01$ & $98 \pm 2.2$ & $94 \pm 2.0$ & NS & $126 \pm 3.2$ & $121 \pm 3.0$ & $<0.01$ \\
\hline 8 & $98 \pm 3.4$ & $119 \pm 6.1$ & $122 \pm 5.0$ & $<0.01$ & $96 \pm 2.0$ & $97 \pm 1.8$ & NS & $124 \pm 3.9$ & $126 \pm 4.1$ & $<0.01$ \\
\hline 12 & $100 \pm 4.1$ & $111 \pm 7.1$ & $112 \pm 6.7$ & NS & $94 \pm 2.1$ & $93 \pm 2.0$ & NS & $112 \pm 3.6$ & $111 \pm 3.6$ & $<0.05$ \\
\hline 23 & $93 \pm 3.5$ & $54 \pm 2.1$ & $57 \pm 2.1$ & $<0.01$ & $94 \pm 1.9$ & $100 \pm 2.0$ & NS & $54 \pm 2.9$ & $58 \pm 3.8$ & $<0.01$ \\
\hline 30 & $58 \pm 3.1$ & $23 \pm 1.8$ & $39 \pm 3.2$ & $<0.01$ & $52 \pm 2.3$ & $90 \pm 4.2$ & NS & $20 \pm 1.8$ & $35 \pm 3.8$ & $<0.01$ \\
\hline
\end{tabular}

Study $2(n=8)$

$0 \quad 94 \pm 1.1$

$2 \quad 99 \pm 1.2$

$395 \pm 1.3$

$590 \pm 0.7$

$10 \quad 77 \pm 2.1$

$22 \quad 59 \pm 1.5$

$26 \quad 53 \pm 1.3$

$30 \quad 48 \pm 1.4$
$94 \pm 1.1$

$111 \pm 1.8$

$107 \pm 0.6$

$100 \pm 0.6$

$89 \pm 0.8$

$71 \pm 1.6$

$43 \pm 0.8$

$22 \pm 0.6$

$\begin{array}{rr}112 \pm 1.8 & <0.01 \\ 113 \pm 1.2 & <0.01 \\ 110 \pm 0.7 & <0.01 \\ 116 \pm 1.0 & <0.01 \\ 120 \pm 2.7 & <0.01 \\ 81 \pm 1.5 & <0.01 \\ 46 \pm 1.3 & <0.01\end{array}$

$94 \pm 1.1$

$105 \pm 0.7$

$92 \pm 1.3$

$85 \pm 0.8$

$71 \pm 0.5$

$55 \pm 2.3$

$49 \pm 1.6$

$42 \pm 0.9$

$\begin{array}{rcr}106 \pm 0.7 & \text { NS } & 94 \pm 1.1 \\ 97 \pm 1.4 & \text { NS } & 108 \pm 1.6 \\ 94 \pm 0.9 & \text { NS } & 106 \pm 0.6 \\ 92 \pm 0.7 & <0.05 & 88 \pm 0.9 \\ 93 \pm 3.4 & \text { NS } & 71 \pm 1.1 \\ 93 \pm 3.1 & \text { NS } & 42 \pm 0.8 \\ 86 \pm 1.9 & <0.05 & 21 \pm 0.6\end{array}$

$\begin{array}{rr}111 \pm 1.6 & <0.01 \\ 114 \pm 1.5 & <0.01 \\ 118 \pm 0.7 & <0.01 \\ 115 \pm 1.2 & <0.01 \\ 120 \pm 1.9 & <0.01 \\ 79 \pm 1.5 & <0.01 \\ 43 \pm 1.3 & <0.01\end{array}$

Study $3(n=5)$

\begin{tabular}{rlrrlcrrrrr}
0 & $88 \pm 1.3$ & $88 \pm 1.3$ & & & $89 \pm 1$ & & NS & $93 \pm 1.4$ & \\
8 & $68 \pm 4.0$ & $79 \pm 3.0$ & $116 \pm 4.4$ & $<0.05$ & $72 \pm 1.2$ & $106 \pm 1.8$ & NS & $80 \pm 0.9$ & $118 \pm 1.3$ & $<0.02$ \\
20 & $75 \pm 3.6$ & $101 \pm 5.4$ & $135 \pm 7.2$ & $<0.01$ & $74 \pm 2.3$ & $98 \pm 2.9$ & NS & $105 \pm 5.4$ & $140 \pm 7.2$ & $<0.01$ \\
26 & $90 \pm 10.0$ & $59 \pm 2.1$ & $61 \pm 2.1$ & $<0.01$ & $104 \pm 12.3$ & $108 \pm 12.8$ & NS & $60 \pm 4.1$ & $63 \pm 4.2$ & $<0.01$ \\
\hline
\end{tabular}

Data are presented as mean \pm SE. NX, nephrectomized; PTX, parathyroidectomized; PTX-NX (PTH), parathyroidectomized-nephrectomized rats treated with PTH. 


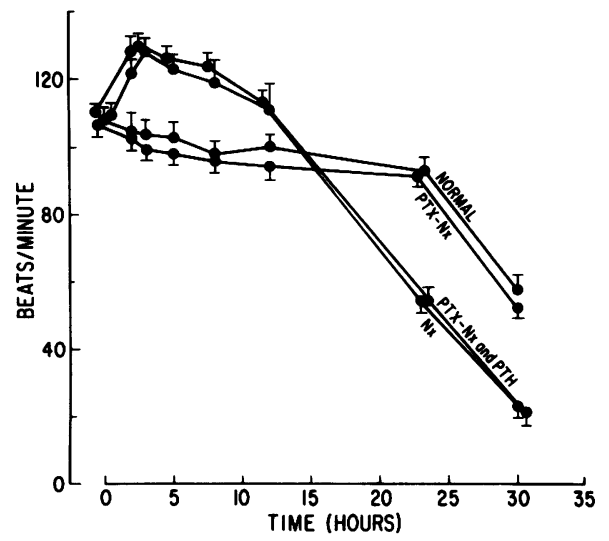

Figure 6 Representative experiment depicting the effect of sera from normal rats, nephrectomized $(\mathrm{Nx})$ rats, parathyroidectomized-nephrectomized rats (PTX-NX), and PTXNX rats treated with PTH (PTX-Nx and PTH). Each point represents the mean $\pm S E$ of seven studies.

effect on the heart cells is consistent with the action being related to the biologic activity of the hormone and not to a contaminant of the hormone preparations.

The reason for the greater effect of 1-84 bPTH than that of 1-34 PTH is not obvious. This observation would suggest that the biologic activity of the intact hormone on the heart is greater than its amino-terminal fragment, and such a phenomenon could be related to a possible effect of the carboxy-terminal fragment on the heart. Our finding that 53-84 PTH did not affect the beating rate does not necessarily vitiate a role for carboxy-terminal PTH on the heart. It is possible that bigger fragment(s) other than the 53-84 are important.

It is well-documented that an increase in the calcium delivery to the myofilaments is responsible for the contraction of heart cells. Indeed, augmented calcium influx occurs in association with positive inotropism accompanied by increased frequency of contraction (37-39), catecholamine administration $(40,41)$, and digitalis $(42,43)$. Several lines of evidence indicate that the effect of PTH on the heart cells is also calcium dependent and is mediated through the augmentation of calcium availability to the heart cells. First, PTH in media containing lower calcium concentration enhanced the beating of the heart cells to levels similar to those seen in media with the next higher calcium concentration; these results are consistent with PTH making more calcium available to the cardiac cells. Supporting our data are the results of Harary et al. (44), which evaluated the effect of noradrenaline, an agent known to augment calcium entry into the heart cells (40), on the beating rate. They found that the frequency of beating decreased upon reducing the calcium concentration in the media, and beating stopped at $0.1 \mathrm{mM} \mathrm{Ca}$; in the presence of noradrenaline, beating was sustained even at a concentration of $30 \mu \mathrm{M} \mathrm{Ca}$, suggesting that the agent made more calcium available to the cells even at low concentration in media. Second, calcium ionophore produced an effect on the heart cells similar to that induced by PTH, and neither of the agents in the presence of the other could cause further increments in the beating rate of the heart cells. Finally, verapamil, which blocks movement of calcium from the media into the cells (45), abolished the effect of PTH. Our conclusion is in line with other observations demonstrating that PTH enhances entry of calcium in other mammalian cells (17-19), and that excess PTH leads to accumulation of calcium in many tissues (23-29), including the heart (30).

Recently, Lhoste et al. (46) evaluated the effect of the amino-terminal fragment of PTH (1-34 PTH) on the isometric contractile force of isolated guinea pig auricles. They found that PTH inhibited the depressant effect of both $l$ - and $d$-propranolol on the contractile force of the auricles. Since both of these agents have membrane-stabilizing activity and since the $l$-isomere has no adrenergic blocking effect, the influence of propranolol is therefore at least partly mediated by its membrane-stabilizing action, which would result in decreasing calcium movement into the myocardial cells (47). Thus, the authors suggested that PTH antagonzes the depressant effect of propranolol on the myocardium by augmenting calcium entry into the cells of the heart. Further support for their claim was provided by their finding that PTH also partially overcame the depressant effect of verapamil on the contractile force of the auricles. These observations agree with our data and provide additional evidence for an interaction between PTH and the heart that is probably mediated by movement of calcium into the heart cells.

The increased entry of calcium into the heart cells under the influence of PTH is likely a consequence of two processes. First, the hormone may directly enhance calcium influx; such a phenomenon has been demonstrated in many mammalian cells (17-22). Second, the stimulation of cyclic AMP production may augment calcium movement into the cells. Several lines of evidence support this notion. Available data indicate that calcium influx into the heart occurs during a slow inward current, which has the characteristics expected of a calcium current (48-50). Butyryl derivatives of cyclic AMP increase the slow inward current $(51,52)$, and dibutyryl cyclic AMP enhances fluxes of tracer calcium into heart cells (53). Finally, agents such as histamine, theophylline, or papaverine, which augment intracellular cyclic AMP of myocardium, promote action potentials that are dependent on slow inward current at a time when fast sodium channels are blocked or inactivted (54-56). The effect of cyclic AMP on calcium movement into the cell is probably mediated through phosphorylation of the 
plasma membrane (57). A role for the increased production of cyclic AMP by PTH on the increased beating of the heart cells is also supported by the observations of Krause et al. (58) that dibutyryl cyclic AMP accelerate the beating of heart cells.

The role of cyclic AMP in cardiac contraction is more complex and extends beyond enhancing calcium influx into the cells. It has been demonstrated that cyclic AMP-dependent protein kinases phosphorylate the membrane of the sarcoplasma reticulum (SR) (59); such phosphorylation permits the uptake of calcium by the SR (59) and results in lowering the amount of calcium available to the myofibrils below that needed for contraction. To prevent the continued uptake of calcium by the SR and the consequent fall in cytosolic calcium to very low levels, the amount of cyclic AMP must be regulated. It has been demonstrated that the accumulation of calcium in and around the SR activates an activator protein that stimulates cyclic AMP-phosphodiesterase $(60,61)$, which in turn increases the degradation of cyclic AMP, leading to a decrease in the phosphorylation of SR membrane (62). This sequence of events would reduce the uptake of calcium by the SR and prevent continued fall in cytosolic calcium. Thus, as has been suggested by Harary and Wallace (63), it appears that calcium in myocardial cytosol may regulate its own concentration by a feedback control mechanism on cyclic AMP. Indeed, Harary et al. (44) provided data supporting this notion. Our observation that PTH produced an immediate rise in cyclic AMP production, which then quickly fell to levels that remained stable but significantly higher than the basal values, are consistent with a new steady state produced by PTH. The hormone increased the production of cyclic AMP and augmented calcium entering into the cells, and through the feedback control process between calcium and cyclic AMP, a new steady state ensued with higher intracellular calcium and cyclic AMP and increased frequency of beating of the heart cells.

Catecholamines are known to affect cardiac contraction $(40,41)$ and to increase beating of heart cells $(44)$ by augmenting calcium entry into the myocardial cells. Certain data in our studies indicate that the channels for calcium entry into heart cells and/or the processes responsible for such movement under the influence of PTH are different from those affected by catecholamines. PTH augmented the beating rate by cells already stimulated with either $\alpha$ - or $\beta$-adrenergic agents, and the latter produced further increments in the beating rate of the cells exposed to PTH. In fact, the interaction between PTH and the $\alpha$-adrenergic agent isoporterenol appeared to be synergistic. Furthermore, $\alpha$ - or $\beta$-blockers did not affect the response of the heart cells to PTH. Thus, it appears that these receptors are not the site of action of PTH.
Fleckenstein (64) has demonstrated that calcium overload of the myocardial cells induced by catecholamines, was associated with a deficiency of highenergy phosphate compound; there was a significant fall in cellular ATP content secondary to both increased ATP consumption and decreased ATP synthesis. Furthermore, Seraydarian et al. (65) have shown that maintenance of normal ATP level is critical for spontaneous beating of heart cells in culture, and a decrease of $30-60 \%$ in cellular ATP was associated with cessation of beating. It is therefore reasonable to suggest that calcium overload of the myocardial cells under the prolonged influence of PTH would be associated with a decrease in their ATP content. Such an event would provide an explanation for the observed decline and final cessation of the beating of the cells after several hours of exposure to PTH.

Our data are consistent with the notion that the elevated blood levels of PTH in uremia enhance calcium influx into the myocardium and affect its function. It is also possible that other compounds retained or produced in excess by the uremic patients have effects on the heart adverse as those of PTH. However, our studies with uremic sera with and without excess endogenous or exogenous PTH clearly demonstrate that uremic sera have no effect on the beating rate of the heart cell unless they contain PTH. Lhoste et al. (46) evaluated the effect of sera obtained from uremic patients with secondary hyperparathyroidism and from uremic patients previously subjected to parathyroidectomy on the contraction of the isolated auticles of the guinea pig. They found that only the uremic sera with excess PTH produced significant inhibition of the depressant effect of propranolol on the contraction of the auricles. Thus, our data and those of Lhoste et al. (46) indicate that it is the PTH, and not other compounds in the uremic sera, that affects myocardial function.

Recently, Drueke et al. (66) reported marked improvement in left ventricular function after parathyroidectomy in 22 dialysis patients with secondary hyperparathyroidism. These observations provide further support for the notion that the elevated blood levels of PTH in patients with uremia may adversely affect myocardial function and could, at least in part, be responsible for uremic myocardiopathy. Finally, the interaction between catecholamines and PTH on the heart, as demonstrated in our study, may expose patients with renal failure to double jeopardy, since these patients may have elevated blood levels of catecholamines (67-69) in addition to secondary hyperparathyroidism.

\section{ACKNOWLEDGMENTS}

We wish to thank Mr. Greg Bristol for his technical assistance and Ms. Melinda J. Ayers for her secretarial help. 
This work was supported by contract AM7-2218 from the Chronic Uremia Program of the National Institute of Arthritis, Metabolism and Digestive Diseases and Department of Energy contract DE AMO3-76-SF-00012.

\section{REFERENCES}

1. Richter, A. B., and J. P. O-Hare. 1936. Heart in chronic glomerulonephritis. N. Engl. J. Med. 266: 1089-1097.

2. Gouley, B. A. 1940. The myocardial degeneration associated with uremia in advanced hypertension disease and chronic glomerulonephritis. Am. J. Med. Sci. 200: 39-53.

3. Solomon, C., J. E. Roberts, and J. R. Lisa. 1942. The heart in uremia. Am. J. Pathol. 18: 729-732.

4. Lagendorf, R., and C. L. Pirani. 1947. The heart in uremia. An electro-cardiographic and pathologic study. Am. Heart. J. 33: 282-307.

5. Derow, H. A. 1954. The heart in renal disease. Circulation. 10: 114-128.

6. Bailey, G. L., C. L. Hampers, and J. P. Merrill. 1967. Trans. Am. Soc. Artif. Intern. Organs. 13: 263-272.

7. Pabico, R. C., and R. B. Freeman. 1976. Pericarditis and myocardiopathy. In Clinical Aspects of Uremia and Dialysis. S. G. Massry and A. L. Sellers, editors. Charles C. Thomas Publisher, Springfield, Ill. 69-99.

8. Linder, A., B. Charra, D. J. Sherrard, and B. H. Scribner. 1974. Accelerated atherogenesis of prolonged maintenance hemodialysis. N. Engl. J. Med. 290: 697-701.

9. Pappenheimer, A. M., and S. L. Wilens. 1935. Enlargement of the parathyroid glands in renal disease. Am. J. Pathol. 11: 73-91.

10. Roth, S. I., and R. B. Marshall. 1969. Pathology and ultrastructure of the human parathyroid glands in chronic renal failure. Arch. Intern. Med. 124: 397-407.

11. Katz, A. I., C. L. Hampers, and J. P. Merrill. 1969. Secondary hyperparathyroidism and renal osteodystrophy in chronic renal failure. Medicine (Baltimore). 48: 333-374.

12. Berson, S. A., and R. S. Yalow. 1966. Parathyroid hormone in plasma in adenomatous hyperparathyroidism, uremia, and bronchogenic carcinoma. Science (Wash. D.C.). 154: 907-909.

13. Massry, S. G., J. W. Coburn, M. Peacock, and C. R. Kleeman. 1972. Turnover of endogenous parathyroid hormone in uremic patients and those undergoing hemodialysis. Trans. Am. Soc. Artif. Intern. Organs. 18: 416-422.

14. Arnaud, C. D. 1973. Hyperparathyroidism and renal failure. Kidney Int. 4: 89-95.

15. Seyle, J. 1961. The Pleuricausal Cardiopathies. Charles C. Thomas Publisher, Springfield, Ill.

16. Lehr, D. 1966. The role of certain electrolytes and hormones in disseminated myocardial necrosis. In Electrolyte and Cardiovascular Disease. E. Bajusz, editor. S. Karger, Basel, Switzerland. 1: 248.

17. Wallach, S., J. V. Bellavia, J. Shorr, and J. Schaffers, 1966. Tissue distribution of electrolytes, $\mathrm{Ca}^{47}$, and $\mathbf{M g}^{28}$ in experimental hyper and hypoparthyroidism. Endocrinology. 78: $16-28$.

18. Borle, A. B. 1968. Calcium metabolism in Hela cells and the effect of parathyroid hormone. J. Cell Biol. 36: 567-582.

19. Borle, A. B. 1968. Effects of purified parathyroid hormone on the calcium metabolism of monkey kidney cells. Endocrinology. 83: 1316-1322.

20. Borle, A. B. 1970. Kinetic analysis of calcium movement in cell cultures. III. Effect of calcium and parathyroid hormone on kidney cells. J. Gen. Physiol. 55: 163-186.

21. Chausmer, A. B., B. S Sherman, and S. Wallach. 1972.
The effect of parathyroid hormone on hepatic cell transport of calcium. Endocrinology. 90: 663-672.

22. Borle, A. B. 1973. Calcium metabolism at the cellular level. Fed. Proc. 30: 1944-1950.

23. Massry, S. G., J. W. Coburn, D. L. Hartenbower, J. H. Shinaberger, J. R. DePalma, E. Chapman, and C. R. Kleeman. 1970. Mineral content of human skin in uremia: effect of secondary hyperparathyroidism and hemodialysis. Proceedings of the European Dialysis and Transplantation Association. 7: 146-150.

24. Berkow, J. W., B. S. Fine, and L. E. Zimmerman. 1968 Unusual ocular calcification in hyperparathyroidism. Am. J. Ophthalmol. 66: 812-824.

25. Bernstein, D. S., P. Pletka, R. S. Hattner, C. L. Hampers, and J. P. Merrill. 1971. Effect of total parathyroidectomy and uremia on the chemical composition of bone, skin, and aorta in the rat. Isr. J. Med. Sci. 7: 513-514.

26. Guisado, R., A. I. Arieff, and S. G. Massry. 1977. Muscle water and electrolytes in uremia and the effects of hemadialysis. J. Lab: Clin. Med. 89: 322-331.

27. Arieff, A. I., and S. G. Massry. 1974. Calcium metabolism of brain in acute renal failure. J. Clin. Invest. 53: 387-392.

28. Goldstein, D. A., and S. G. Massry. 1978. Effect of parathyroid hormone administration and its withdrawal on brain calcium and electroencephalogram. Miner. Electrolyte Metab. 1: 84-91.

29. Goldstein, D. A., L. A. Chui, and S. G. Massry. 1978. Effect of parathyroid hormone and uremia on peripheral nerve calcium and motor nerve conduction velocity. J. Clin. Invest. 62: 88-93.

30. Kraikipanitch, S., R. D. Lindeman, A. A. Yoenice, D. J. Baxter, C. C. Haygood, and M. M. Blue. 1978. Effect of azotemia and myocardial accumulation of calcium. Miner. Electrolyte Metab. 1: 12-20.

31. Fleckenstein, A., J. H. Doring, and D. Leder. 1969. The significance of high-energy phosphate exhaustion in the etiology of isoproterenol-induced cardiac necrosis and its prevention by iproveratril, compound D600 or prenylamine. In International Symposium on Drugs and Metablism of Myocardium and Striated Muscle. M. Lamarch and R. Royer, editors, Nancy. 11-22

32. Harary, I. 1979. Biochemistry of cardiac development: in vivo and in vitro studies. In Handbook of PhysiologyThe Cardiovascular System I. R. M. Berne, N. Sperelakis, and S. R. Geiger, editors. American Physiology Society. 43-60.

33. Harary, I. and B. Farley. 1963. In vitro studies of heart cells in culture. I. Growth and organization. Exp. Cell Res. 29: 451-465.

34. Masse, M. J. O., and I. Harary. The use of fluorescent antimycin and DNA labelling for the estimation of the myoblast and myocyte population of primary rat heart cell cultures. J. Cell. Physiol. In press.

35. Steiner, A. L., A. S. Pagliara, L. R. Chase, and D. M. Kipnis. 1972. Radioimmunoassay for cyclic nucleotides. II. Adenosine $3^{\prime}, 5^{\prime}$-monophosphate and guanosine $3^{\prime}, 5^{\prime}$ monophosphate in mammalian tissues and body fluids. J. Biol. Chem. 247: 1114-1120.

36. Lowry, O. H., N. J. Rosebrough, A. L. Farr, R. J. Randall. 1951. Protein measurement with the Folin phenol reagent. J. Biol. Chem. 193: 265-275.

37. Langer, G. A., and A. J. Brady. 1963. Calcium flux in the mammalian ventricular myocardium. J. Gen. Physiol. 46: 703-719.

38. Neidergerke, R. 1963. Movement of calcium in beating ventricles of the frog heart. J. Physiol. (Lond.). 167: $551-580$. 
39. Sands. S. D., and S. Winegrad. 1970. Trapped and total calcium content of frog ventricle. Am. J. Physiol. 218: 908-910.

40. Reuter, H. 1965. Uber die Wirkung von Adrenalin auf den cellularen Ca-urusatz des Meerschweinvorhofs. Naunyn-Schmiedebergs Arch. Exp. Pathol. Pharmakol. 251: 401

41. New, W., and W. Trautwein. 1972. Inward currents in mammalian myocardium. Pflugers Arch. 334: 1-23.

42. Langer, G. A., and S. D. Serena. 1970. Effects of strophanthidin upon contraction and ionic exchange in rabbit ventricular myocardium: relation to control of active state. J. Mol. Cell. Cardiol. 1: 65-90.

43. Bailey, L. E., and H. A. Sures. 1971. The effect of ouabain on the washout and uptake of calcium in the isolated cat heart. J. Pharmacol. Exp. Ther. 178: 259-270.

44. Harary, I., J. F. Renaud, E. Sato, and G. A. Wallace. 1976. Calcium ions regulate cyclic AMP and beating in cultured heart cells. Nature (Lond.) 261: 60-61.

45. Kohlhardt, D. T. A., B. Bauer, H. Krause, and A. Fleckenstein. 1972. Differentiation of the transmembrane $\mathrm{Na}$ and Ca channels in mammalian cardiac fibres by use of specific inhibitors. Pflugers Arch. 335: 309-322.

46. Lhoste, F., T. Drueke, S. Larus, and J. R. Boissier. 1980. Cardiac interaction between parathyroid hormone, $\beta$ adrenoreceptor, and verapamil in the guinea pig in vitro. Clin. Exp. Pharmacol. Physiol. 7: 377-385.

47. Nayler, W. G. 1967. Some factors involved in the maintenance and regulation of cardiac contractility. Circ. Res. 21: (Suppl. III): 213-221.

48. Morad, M., and Y. Goldman. 1973. Excitation-contraction coupling in heart muscle: membrane control of development of tension. Prog. Biophys. Mol. Biol. 27: $257-313$.

49. Reuter, H. 1973. Divalent cations as charge carriers in excitable membranes. Prog. Biophys. Mol. Biol. 26: $1-43$.

50. Trautwein, W. 1973. Membrane currents in cardiac muscle fibers. Physiol.Rev. 53: 793-835.

5l. Tsien, R. W., W. R. Giles, and P. Greengard. 1972. Cyclic AMP mediates the action of adrenaline on the action potential plateau of cardiac purkinje fibres. Nature (Lond.) 240: 181-183.

52. Reuter, H. 1974. Localization of $\beta$-adrenergic receptors, and effects of noradrenaline and cyclic nucleotides on action potentials, ionic currents and tension in mammalian muscle. J. Physiol. (Lond.). 227: 429-451.

53. Meinertz, T., H. Nowrath, and H. Schaltz. 1973. Stimulatory effects of db-c-AMP and adrenaline on myocardial contraction and ${ }^{45}$-Ca exchange: experiments at reduced calcium concentration and low frequencies of stimulation. Naunyn-Schmiedebergs Arch. Pharmakol. 279: 327-338.

54. Watanabe, A. M., and H. R. Besch. 1974. Cyclic adenosine monophosphate modulation of slow calcium influx channels in guinea pig hearts. Circ. Res. 35: 316-327.

55. Watanabe, A. M., and H. R. Besch. 1975. The relationship between adenosine 3',5'-monophosphate levels and systolic transmembrane calcium flux. Recent Adv. Stud. Card. Struct. Metab. 5, 95-101.
56. Sperelakis, N., and J. A. Schenider. 1976. A metabolic control mechanism for calcium ion influx that may protect the ventricular myocardial cell. Am. J. Cardiol. 37: 1079- 1085.

57. Hui, C. H., M. Drummond, and G. I. Drummond. 1976. Calcium accumulation and cyclic AMP stimulated phosphorylation in plasma membrane-enriched preparation of myocardium. Arch. Biochem. Biophys. 173: 415-427.

58. Krause, E. G., W. Halle, E. Kallakis, and A. Wallenberger. 1970. Positive chronotrophic response of cultured isolated heart cells to $\mathrm{N}^{6}-2^{\prime}$-Odibutyryl-adenosine monophosphate. J. Mol. Cell. Cardiol. 1: 1-10.

59. Kirchberger, M. A., M. Toda, D. I. Repke, and A. M. Katz. 1972. Crclic adenosine $35^{\prime} 5^{\prime}$-monophosphate-dependent protein kinase stimulation of calcium uptake by canine cardiac microsome. J. Mol. Cell. Cardiol. 4: 643-680.

60. Kakinshi, S., and R. Yamazaki. 1970. Calcium dependent phosphodiesterase activity and its activating factor from brain. Biochem. Biophys. Res. Commun. 41: 1104-1110.

61. Teo, T. S., and J. H. Wang. 1973. Mechanism of activation of a cyclic adenosine $3^{\prime}, 5^{\prime}$-monophosphate phosphodiesterase from bovine heart by calcium ions. J. Biol. Chem. 248: 5950-5955.

62. Tada, M., M. A. Kirchberger, and H. C. Li. 1975. Phosphoprotein phosphatase-catalyzed dephosphorylation of 22,000 dalton phosphoprotein of cardiac sarcoplasmic reticulum. J. Cyclic Nucleotide Res. 1: 329-338.

63. Harary, I., and G. A. Wallace. 1978. The effect of the reciprocal relationship of $\mathrm{Ca}^{2+}$ and cAMP on the control of beating in cultured rat heart cells. Recent Adv. Stud. Card. Struct. Metab. 12: 635-643.

64. Fleckenstein, A. 1971. Specific inhibitors and promoters of calcium action in the excitation-contraction coupling of heart muscle and their role in the prevention or production of myocardial lesions. In Calcium and the Heart. P. Harris and L. Opie, editors. Academic Press, Inc., New York. 135-188.

65. Seraydarian, M. W., I. Harary, and E. Sato. 1968. In vitro studies of beating-heart cells in culture. XI. The ATP level and contractions of the heart cells. Biochim. Biophys. Acta. 162: 414-423.

66. Drueke, T., I. Fleury, Y. Toure, P. DeVernejoul, M. Fauchet, P. Lesourd, C. LePailleur, and J. Crosnier. 1980. Effect of parathyroidectomy on left-ventricular function in haemodialysis patients. Lancet. I: 112-114.

67. Atuk, N. O., C. J. Bailey, S. Turner, M. J. Peach, and F. B. Westervelt, 1976. Red blood cell catechol-o-methyl transferase, plasma catecholamines and renin in renal failure. Trans. Am. Soc. Artif. Intern. Organs. 22: 195-200.

68. Brecht, H. M., W. Ernst, and K. M. Koch. 1975. Plasma moradrenaline levels in regular hemodialysis. Proc. Eur. Dial. Transplant. Assoc. 12: 281-289.

69. Campese, V. M., M. S. Romoff, D. Levitan, L. Lane, and S. G. Massry, 1979. Reduced end-organ response to norepinephrine in uremia: a mechanism of autonomic dysfunction. Proc. Am. Soc. Nephrol. 12: 181A. 